\title{
Characterization of microbial communities in wetland mesocosms receiving caffeine-enriched wastewater
}

\author{
Dongqing Zhang ${ }^{1} \cdot$ Jinxue Luo ${ }^{2,3}$ - Zarraz May Ping Lee ${ }^{1}$ Richard M. Gersberg ${ }^{4}$. \\ Yu Liu ${ }^{1,5}$ • Soon Keat Tan ${ }^{1,5}$ • Wun Jern Ng ${ }^{1,5}$
}

Received: 5 January 2016 / Accepted: 28 March 2016 / Published online: 12 April 2016

(C) Springer-Verlag Berlin Heidelberg 2016

\begin{abstract}
A 454 high-throughput pyrosequencing approach was used to characterize the structures of microbial communities in wetland mesocosms receiving caffeine-enriched wastewater at a concentration of $250 \mu \mathrm{g} \mathrm{L}^{-1}$. The removal efficiencies of caffeine in the planted beds $(93.0 \%)$ were significantly $(p<0.05)$ higher than those in the unplanted beds (81.4\%). Bacterial diversity was decreased by 25 and $22.4 \%$, respectively, in both planted and unplanted mesocosms after 210-day operation. The results of taxonomic analyses suggested that chronic exposure of wetland ecosystems to caffeine could lead to moderate shifts in microbial community composition. In total, 2156 operational taxonomic units (OTUs) were generated and 20 phyla comprising 260 genera were identified. The major phylogenetic groups at phylum level included Firmicutes (39 \%), Actinobacteria (25.1\%), Proteobacteria (17.1\%), Synergistetes (5.6\%), and Chloroflexi (5.5\%).
\end{abstract}

Responsible editor: Robert Duran

Dongqing Zhang and Jinxue Luo contributed equally to this work.

Electronic supplementary material The online version of this article (doi:10.1007/s11356-016-6586-4) contains supplementary material, which is available to authorized users.

Wun Jern $\mathrm{Ng}$

WJNg@ntu.edu.sg

Dongqing Zhang

dqzhang@ntu.edu.sg

1 Advanced Environmental Biotechnology Center, Nanyang Environment and Water Research Institute, Nanyang Technological University, 1 Cleantech Loop, No. 06-10, Singapore 637141, Singapore
Bacilli and Synergistia increased in abundance in the planted mesocosms, while for the unplanted mesocosms, Actinobacterial, Clostridia and Betaproteobacteria exhibited increased proportion under the exposure of caffeine. At genus level, Propionibacterium, Staphylococcus, Bacillus, and Streptococcus were found to be increased in abundance after caffeine treatment. As for the response of fungal community to caffeine enrichment, genus like Cladosporium, Emericellopsis, Aspergillus, and Phoma were found to be resistant to caffeine disturbance. When compared to the microbial community between planted and unplanted mesocosms, a distinct community profile for both bacteria and fungi community was observed. The presence of plants had a remarkable effect on the structure of microbial community, helping buffer against the stress associated with caffeine exposure.
2 Key Laboratory of Environmental Biotechnology, Research Center for Eco-Environmental Sciences, Chinese Academy of Sciences, Beijing 100085, People's Republic of China

3 CAS.WEE (Beijing) Eco-Engineering Technology Institute Co., Ltd, Beijing 100035, China

4 Graduate School of Public Health, San Diego State University, Hardy Tower 119, 5500 Campanile, San Diego, CA 92182-4162, USA

5 School of Civil and Environmental Engineering, Nanyang Technological University, N1-01a-29, 50 Nanyang Avenue, Singapore 639798, Singapore 
Keywords Constructed wetland · Caffeine ·

Microbial community $\cdot$ High-throughput pyrosequencing

\section{Introduction}

Caffeine (3,7-dihydro-1,3,7-trimethyl-1 h-purine-2,6-dione), a purine alkaloid, is the most commonly used legal drug in the world and has been added onto the US Environmental Protection Agency's list of high production volume of chemicals (Buerge et al. 2003; Mohapatra et al. 2006). In a recent review on the occurrence and fate of 137 micropollutants, Verlicchi and Zambello (2014) reported that caffeine has typically been detected in wastewater treatment plants (WWTPs) at concentrations ranging from 0.22 to $209 \mu \mathrm{g} \mathrm{L}^{-1}$ in influent and up to $43.5 \mu \mathrm{g} \mathrm{L}^{-1}$ in effluent. Since conventional WWTPs are not uniquely designed for the elimination of micropollutants (Joss et al. 2006), caffeine has been inevitably discharged into aquatic receiving systems (Buerge et al. 2003; Kolpin et al. 2002). Once discharged, due to its high solubility in water $\left(37.5 \mathrm{~g} \mathrm{~L}^{-1}\right)$ and high hydrophilicity with a low $\log K_{\text {ow }}$ value of -0.07 (Thomas and Foster 2005), caffeine, a non-ionizable and polar compound, can act as a persistent chemical in the environment (Rosal et al. 2009). Despite its low concentrations in aquatic systems, ecotoxicological studies have revealed that caffeine could still exert chronic adverse effects on aquatic ecosystems (Martinez Gomez et al. 2015; Moore et al. 2008). Results of caffeine toxicity tests revealed $\mathrm{LC}_{50}$ levels of $182 \mathrm{mg} \mathrm{L}^{-1}$ for Daphnia magna (Solomon et al. 1996), 130-190 $\mathrm{mg} \mathrm{L}^{-1}$ for Xenopus laevis (Moore et al. 2008), and $200 \mathrm{mg} \mathrm{L}^{-1}$ for Plationus patulus (Martinez Gomez et al. 2015). Additional studies have engendered increasing heightened concern about caffeine's prevalence in combination with other chemical compounds in wastewaters (Moore et al. 2008). Therefore, the potential harm of this alkaloid has drawn great interest in the research on caffeine elimination and its degradation in the aquatic environment.

Over last decade, a number of studies have shown that treatment using constructed wetlands (CWs) can remove the stimulant caffeine with high removal efficiencies, e.g., 97 and $99 \%$ for horizontal and vertical subsurface flow CWs (Matamoros et al. 2009) and 83-99\% for free-floating and submerged wetlands (Matamoros et al. 2012). With a low $K_{\text {ow }}$ value of -0.07 , caffeine should not adsorb well to sediment (Thomas and Foster 2005). Therefore, the primary removal mechanism for caffeine is biological in origin. Although plant roots can take up caffeine which may be then translocated to shoot tissues (Zhang et al. 2013), biodegradation by microbes associated with the plant rhizosphere is considered as the most important pathway for caffeine removal (Hijosa-Valsero et al. 2010; Matamoros et al. 2012; Zhang et al. 2014). Microorganisms inhabiting CWs play an important role in biogeochemical cycling, making them key components of bioremediation processes (Truu et al. 2009). In CWs, the coexistence of variety of microbial communities among water, substrate media, and plant compartments might offer suitable ecological niches to support a diversity of metabolic pathways leading to micropollutant biodegradation (Hijosa-Valsero et al. 2010). Because wastewater treatment is for the most part a biodegradation-driven process, characterizing the structure of microbial communities is the key to understanding the biological processes that occur in wetland systems and can provide a basis for the rational design and operation of these engineered ecosystems (Dong and Reddy 2010). Additionally, understanding the structure of microbial communities may allow the precise prediction of the specific microbial players responsible for the degradation of organic pollutants (Johnsen et al. 2002). Although the bacterial diversity in CWs has been described in a few studies (Ligi et al. 2014; Arroyo et al. 2015), up to the present, the microbial diversity of treatment wetlands has not been well addressed, and there is still little understanding of the role that the higher aquatic plants play in influencing the microbial community structure in treatment wetlands (Stottmeister et al. 2003).

More recently, 454 high-throughput pyrosequencing technology has become an effective method to fully explore the microbial diversity in aquatic systems (Roesch et al. 2007; Roh et al. 2010). Compared to conventional molecular technologies such as fluorescence in situ hybridization (FISH), denaturing gradient gel electrophoresis (DGGE), and terminal restriction fragment length polymorphisms (T-RFLP), highthroughput pyrosequencing approach can improve read lengths allowing for a highly accurate phylogenetic-based classification of individual reads (Ye et al. 2011). Particularly, it can reveal the presence of unculturable organisms and low-abundance organisms that are usually overshadowed by dominant populations in the aquatic environment (Roh et al. 2010). This technology has been widely used to investigate the microbial community structure in a variety of environments, such as those from submerged membrane bioreactors (Ma et al. 2013), activated sludge processes (Ye et al. 2011), and forest soils (Buée et al. 2009). However, very few studies using such a pyrosequencing approach have addressed the microbial structure in wetland ecosystems receiving pharmaceutical compounds (Zhao et al. 2015). Therefore, in the present study, we used high-throughput pyrosequencing approach to gain comprehensive taxonomic information and characterize the microbial profile under the disturbance of caffeine at the concentration of $250 \mu \mathrm{g} \mathrm{L}^{-1}$. Table 1 presents the physicochemical properties of caffeine. The primary objective of this research was to determine the effect of caffeine on the structure of microbial community and the role that the higher aquatic plants play in determining the composition of these bacterial communities in CWs. 
Table 1 Physicochemical properties of caffeine

\begin{tabular}{l}
\hline Structure \\
IUPAC name \\
CAS no. \\
Formula \\
Molecular weight \\
Chemical function \\
Metabolism \\
Water solubility \\
Half life
\end{tabular}

${ }^{\text {a }}$ Physical Properties (PHYSPROP) database

${ }^{\mathrm{b}}$ ChemAxon Marvin Calculator software was used to calculate $\log D_{\mathrm{ow}}$

\section{Materials and methods}

\section{Description of the mesocosm-scaled CWs}

Four identical mesocosms including two horizontal subsurface flow (HSSF) CWs planted with cattail (Typha angustifolia) at a density of 15 plant $\mathrm{m}^{-2}$ and two unplanted mesocosms were set up in parallel at the campus of Nanyang Technological University, Singapore ( $\left.1^{\circ} 22^{\prime} \mathrm{N}, 130^{\circ} 48^{\prime} \mathrm{E}\right)$. The location is a typical tropical environment and is generally hot and humid year round. The temperature ranges from 23 to $32{ }^{\circ} \mathrm{C}$. There is no distinct wet/dry season and most rainfall occurs during the northeast monsoon (November to January) when the rainfall is usually sudden and heavy.

The four mesocosms were separated among two groups, one spiked with caffeine while the other serving as control. The dimensions of each (made of fiberglass) was $1.2 \mathrm{~m}$ $(L) \times 0.6 \mathrm{~m}(W) \times 0.6 \mathrm{~m}(D)$. The mesocosms were filled with a substrate which was composed of two layers, a bottom layer of gravel (300 mm, $\left.D_{60}=4-10 \mathrm{~mm}\right)$ and an upper layer of loamy sand $\left(100 \mathrm{~mm} ; 75 \%\right.$ of sand particles with $D_{60}=1-$ $2 \mathrm{~mm}, 23 \%$ silt particles, and $2 \%$ clay particles; Supplementary Fig. 1). At the bottom of each mesocosm, a horizontal drainage pipe $(0.4 \mathrm{~m}$ long and $50 \mathrm{~mm}$ in diameter $)$ with outlet valves was located for effluent sampling.

\section{System operation and sampling regime}

The experiment lasted 210 days. All the systems were acclimatised for 90 days with daily flooding using synthetic wastewater so as to allow the microbial biofilms to develop prior to the start of the study. The preparation of synthetic wastewater and caffeine stock solution was described by Zhang et al. (2012a, b). Synthetic wastewater was rapidly filled in each bed from the tank surface of one side. Water depth was maintained at $5 \mathrm{~cm}$ below gravel surface to ensure subsurface flow. Holding tanks of $150-\mathrm{L}$ capacity served as the reservoir for dispensing synthetic wastewater. Batch modes were conducted at a hydraulic loading rate of $2.8 \mathrm{~cm}_{\text {day }}{ }^{-1}$, which resulted in a hydraulic retention time (HRT) of 4 days. Water depth was kept at $5 \mathrm{~cm}$ below the gravel surface.

Wetland effluent samples were collected on a weekly basis in order to measure dissolved oxygen (DO), conductivity, chemical oxygen demand (COD), $\mathrm{NH}_{4}{ }^{+}-\mathrm{N}$, phosphate $\left(\mathrm{PO}_{4}{ }^{3}\right.$ ${ }^{7}$ ), and caffeine concentrations. Every 2 months, the substrate media were collected from the four different wetland mesocosms for microbial community analysis. In each planted and unplanted system, three samples of substrate media were taken at a depth of $5 \mathrm{~cm}$ from the surface at random positions in the mesocosm and places in a polyethylene bag. All samples were placed on ice until arrival in the laboratory for 
further processing. In the laboratory, three samples in each bag were mixed completely to produce a homogeneous sample for each of the mesocosms. All visible plant materials were removed before homogenization. After mixing, subsamples were taken from each plastic bag and transferred to a microtube $(2 \mathrm{~mL})$ for DNA extraction. Tubes were stored in a freezer $\left(\right.$ at $-80^{\circ} \mathrm{C}$ ) until molecular analysis was conducted.

\section{Analytical procedures for physicochemical parameters and caffeine}

Caffeine (99.9\% purity) was obtained from Sigma-Aldrich (Singapore). HPLC-grade solvents (acetonitrile, methanol, hexane, and ethyl acetate) were obtained from Fisher (USA). Solid phase extraction (SPE) cartridges (GracePureTM C18; $500 \mathrm{mg}, 6 \mathrm{~mL}$ ) were from Grace Davison Discovery Sciences (Belgium). The HPLC column (Inertsil ODS; $35 \mu \mathrm{m}$; $4.6 \times 150 \mathrm{~mm}$ ) was purchased from Alpha Analytical (Singapore).

Physicochemical parameters analyzed within $24 \mathrm{~h}$ using spectrophotometer (HACH-DR 3800, USA) based on Standard Methods (APHA 1998) included COD, nitrate nitrogen $\left(\mathrm{NO}_{3}-\mathrm{N}\right)$, ammonium nitrogen $\left(\mathrm{NH}_{4}-\mathrm{N}\right)$, and $\mathrm{PO}_{4}{ }^{3-}$. DO, $\mathrm{pH}$, and conductivity were all measured with a portable MultiParameter Digital Meter (HACH-HQ40d, USA).

The concentration of caffeine was analyzed according to procedures previously described (Zhang et al. 2012b). In brief, $500 \mathrm{~mL}$ of effluent wastewater was filtered through a $0.45-\mu \mathrm{m}$ glass fiber membrane filter (Millipore, USA), and then SPE was conducted prior to chromatographic analysis. Water was percolated through the SPE cartridges at a flow rate of approximately $10 \mathrm{~mL} \mathrm{~min}{ }^{-1}$. The SPE cartridges were then eluted with $5 \mathrm{~mL}$ ethyl acetate. The eluent was then concentrated to ca. $400 \mu \mathrm{L}$ in a nitrogen stream and then reconstituted to $500 \mu \mathrm{L}$ with methanol.

A Shimadzu Ultra Fast Liquid Chromatography (UFLC; Shimadzu, Japan) instrument equipped with a SPD-M20A diode array detector (DAD) was used for caffeine quantitative analysis. Chromatography was accomplished using an Inertsil ODS-3 $(4.6 \times 150 \mathrm{~mm}, 5 \mu \mathrm{m}) \mathrm{HPLC}$ column protected by a C18 guard column (Alpha Analytical, Singapore).
Chromatography data acquisition and management was done using a "Shimadzu LCSolution program."

\section{DNA extraction and polymerase chain reaction}

Approximately $0.25 \mathrm{~g}$ of the substrate media was the used for DNA extraction. DNA for genomic analysis was first extracted using a Fast DNA Spin Kit for Soil (MP Biomedicals, USA). DNA purity was verified by the 260/282 and 260/ 230-nm absorption ratios, measured using a ND-2000 spectrophotometer (NanoDrop Inc., Wilmington, DE). Then, the DNA purity was analyzed using agarose gel electrophoresis $(1.1 \%)$ stained with ethidium bromide solution. No additional purification procedure was needed for any of the samples.

Both 16S (bacteria) and 18S (fungal) ribosomal DNA fragments were amplified using a DNA thermocycler (Eppendorf, Germany) with universal primers for the V1-V3 regions of the $16 \mathrm{~S}$ and 18S rRNA genes (Table 2). Polymerase chain reaction (PCR) amplification was performed according to the methodology and conditions given in Zhang et al. (2015).

\section{Processing of pyrosequencing data}

DNA samples were analyzed by Research and Testing Laboratory (Lubbock, TX) using bacterial tag-encoded FLX amplicon pyrosequencing (bTEFAP) (Dowd et al. 2008). The MOTHUR bioinformatics software package (version 1.3) was used for processing the sequencing (Schloss et al. 2009). First, the raw reads were trimmed for adapters, bar codes, and primers. Then, the trimmed sequences were screened for length (minimum $=200)$, homopolymers $($ maximum $=8)$, ambiguous bases ( 0 allowed), and quality (average $=25$ ). Sequences passing these criteria were then aligned against the non-redundant SILVA ribosomal RNA database (Quast et al. 2013). Chimera detection was carried out with UCHIME within MOTHUR followed by taxonomic classification of bacterial sequences using Ribosomal Database Project (RDP) training set as reference, with a confidence value of $80 \%$. If sequences showed similarities below these criteria, they were classified into unidentified groups for each taxonomic rank. A distance matrix was constructed at a $3 \%$
Table 2 Oligonucleotide primers used for polymerase chain reaction $(\mathrm{PCR})$ amplification

\begin{tabular}{clc}
\hline & $\begin{array}{l}\text { Primer consensus sequence } \\
\text { Position (length) }\end{array}$ & Reference \\
\hline $\begin{array}{c}\text { Bacteria-16S rDNA } \\
\text { Forward position } \\
\text { Reverse position }\end{array}$ & Gray 28F (5'-GAGTTTGATCNTGGCTCAG-3') & (Baker et al. 2003) \\
$\begin{array}{c}\text { Fungi-18S rDNA } \\
\text { Forward position }\end{array}$ & funSSUF (5'-TGGAGGGCAAGTCTGGTG-3') & \\
Reverse position & funSSUR (5'-TCGGCATAGTTTATGGTTAAG-3') & (Foster et al. 2013) \\
\hline
\end{tabular}


dissimilarity. After all the sequence processing, a total of 20, 482 remaining sequences were clustered into operational taxonomic units (OTUs) using the furthest neighbor method. The closest relative for representative sequence of each OTU was identified using RDP SeqMatch. A phylogenetic tree was created using MEGA6 with bootstrap calculation using a nucleotide substitution model.

All DNA sequences had been deposited to the Sequence Read Archive of NCBI. The accession numbers of sequence data packets are SRR2177520, SRR2177522, SRR2177522, SRR2182154, SRR2182155, SRR2182157, SRR2182159, SRR2182160, SRR2182171-SRR2182175, SRR2182224, SRR2182226, SRR2182368-SRR2182370, SRR2182372, SRR2182428, SRR2182438, SRR2182469, SRR2182472SRR2182474, and SRR2182493.

\section{Statistical analysis}

The total number of bacterial 16S ribosomal DNA (rDNA) sequences was 27,458, and the average value was 2112 . Four-hundred fifty-four high-throughput pyrosequencing technology provided great unique sequence coverage $(>95 \%)$ for each individual sample. The libraries were then normalized by randomization to the smallest library to avoid unequal sampling bias when computing the diversity indices. For the calculation of relative abundance, $\alpha$-diversity indices (Shannon-Wiener indices $\left(H^{\prime}\right)$, Simpson's diversity indices, and Shannon evenness indices $\left(J^{\prime}\right)$ ) of each sample, the R program (v.2.14.2, http://www.r-project.org/) was used with the output of MOTHUR. Non-metric multidimensional scaling (NMDS) was created using Bray-Curtis similarity matrices with PRIMER-E (version 6) in order to visualize the effect of caffeine on the bacterial community profile. Statistical differences in bacterial community structure and composition between planted and unplanted mesocosms were conducted by assessing significance $(p<0.05)$ through analyses of variance (one-way ANOVA; SPSS v.15.0).

\section{Results and discussion}

\section{Performance of wetland systems}

Results of the analyses of the conventional parameters in the $\mathrm{CW}$ mesocosms are summarized in Table 3 . As has been previously reported for other treatment wetlands (Zhang et al. 2012a), the overall average removal efficiencies of traditional parameters (e.g., $\mathrm{COD}, \mathrm{NH}_{4}{ }^{+}-\mathrm{N}, \mathrm{NO}_{3}{ }^{-}-\mathrm{N}$, and $\mathrm{PO}_{4}{ }^{3-}$ ) were higher in the planted beds compared to the unplanted beds. Similarly, the removal efficiencies of caffeine in the planted beds $(93.0 \%)$ were significantly $(p<0.05)$ higher than those in the unplanted beds $(81.4 \%)$. In a previous review conducted by Verlicchi and Zambello (2014), average caffeine removal efficiencies of $84 \%$ in HSSF CWs and $62 \%$ for the unplanted wetlands were reported. By comparison, the relatively higher removal efficiencies for caffeine observed in the present study ( 81.4 and $93.0 \%$ in the unplanted and planted mesocosms) might be due to the tropical environment, since microorganisms living in CWs typically attain their optimal activity at $25^{\circ} \mathrm{C}$ (Truu et al. 2009).

\section{Richness and diversity of microbial communities}

In this study, a $97 \%$ similarity cutoff was used to delineate OTUs in the downstream analysis using the pyrosequencing approach. Among the large diversity of sequences in the 16S

Table 3 Average concentrations of traditional parameters and caffeine, as well as removal efficiencies (percent in the parentheses)

\begin{tabular}{|c|c|c|c|c|c|}
\hline & \multirow[t]{3}{*}{ Inlet } & \multicolumn{4}{|l|}{ Outlet } \\
\hline & & \multicolumn{2}{|l|}{ Planted HSSF CWs } & \multicolumn{2}{|c|}{ Unplanted HSSF CWs } \\
\hline & & Control & Caffeine treatment & Control & Caffeine treatment \\
\hline \multicolumn{6}{|l|}{ Conventional parameters } \\
\hline $\mathrm{pH}$ & $7.7 \pm 0.2$ & $6.9 \pm 0.1$ & $6.6 \pm 0.2$ & $6.5 \pm 0.2$ & $6.3 \pm 0.3$ \\
\hline Conductivity $\left(\mathrm{S} \mathrm{m}^{-1}\right)$ & $457 \pm 13$ & $423 \pm 36$ & $405 \pm 47$ & $391 \pm 51$ & $479 \pm 63$ \\
\hline $\mathrm{DO}\left(\mathrm{mg} \mathrm{L}^{-1}\right)$ & $7.6 \pm 0.5$ & $4.0 \pm 1.6$ & $3.7 \pm 2.0$ & $3.1 \pm 0.9$ & $2.9 \pm 1.4$ \\
\hline $\operatorname{COD}\left(\mathrm{mg} \mathrm{L}^{-1}\right)$ & $306 \pm 17$ & $18.8 \pm 3.1(93.9 \%)$ & $22.4 \pm 6.1(92.7 \%)$ & $38.4 \pm 8.9(87.5 \%)$ & $49.8 \pm 14.1(83.7 \%)$ \\
\hline $\mathrm{NH}_{4}{ }^{+}-\mathrm{N}\left(\mathrm{mg} \mathrm{L}^{-1}\right)$ & $28.4 \pm 4.1$ & $6.1 \pm 1.9(78.5 \%)$ & $5.7 \pm 2.1(79.9 \%)$ & $10.5 \pm 3.3(63.0 \%)$ & $11.7 \pm 4.8(58.8 \%)$ \\
\hline $\mathrm{NO}_{3}{ }^{-}-\mathrm{N}\left(\mathrm{mg} \mathrm{L}^{-1}\right)$ & $9.5 \pm 0.9$ & $1.6 \pm 0.3(83.2 \%)$ & $1.3 \pm 0.4(86.3 \%)$ & $4.5 \pm 0.6(52.6 \%)$ & $3.1 \pm 0.4(67.4 \%)$ \\
\hline $\mathrm{PO}_{4}^{3-}\left(\mathrm{mg} \mathrm{L}^{-1}\right)$ & $22 \pm 2.8$ & $9.1 \pm 2.6(58.6 \%)$ & $8.5 \pm 2.1(61.3 \%)$ & $11.8 \pm 3.7(46.4 \%)$ & $12.4 \pm 3.7(43.4 \%)$ \\
\hline \multicolumn{6}{|l|}{ Pharmaceutical compounds } \\
\hline Caffeine $\left(\mu \mathrm{g} \mathrm{L}^{-1}\right)$ & 250 & - & $17.5 \pm 8.7(93.0 \%)$ & - & $46.5 \pm 17.1(81.4 \%)$ \\
\hline
\end{tabular}

“ \pm ” represents standard deviation 
Table 4 Summary of sequencing data for initial, control (C), and different treatment (T)

\begin{tabular}{|c|c|c|c|c|c|c|c|c|c|c|c|c|c|}
\hline & \multirow[t]{3}{*}{ Initial } & \multicolumn{6}{|c|}{ Planted HSSF CWs } & \multicolumn{6}{|c|}{ Unplanted HSSF CWs } \\
\hline & & \multicolumn{3}{|l|}{ Control } & \multicolumn{3}{|c|}{ Treatment } & \multicolumn{3}{|c|}{ Control } & \multicolumn{3}{|c|}{ Treatment } \\
\hline & & P1_C & $\mathrm{P} 2 \_\mathrm{C}$ & P3_C & P1_T & $\mathrm{P} 2 \_\mathrm{T}$ & P3_T & S1_C & S2_C & $\mathrm{S} 3 \_\mathrm{C}$ & $\mathrm{S} 1 \_\mathrm{T}$ & $\mathrm{S} 2 \_\mathrm{T}$ & S3_T \\
\hline \multicolumn{14}{|l|}{ Bacteria } \\
\hline OTU numbers & 16 & 142 & 83 & 78 & 137 & 35 & 40 & 19 & 25 & 56 & 33 & 45 & 49 \\
\hline Chao richness & 23 & 415.25 & 122.18 & 117.06 & 404.63 & 63.5 & 117 & 21 & 25.5 & 123.67 & 37.5 & 55.46 & 67.75 \\
\hline Shannon evenness $\left(J^{\prime}\right)$ & 0.7 & 0.95 & 0.94 & 0.9 & 0.96 & 0.66 & 0.8 & 0.8 & 0.54 & 0.84 & 0.77 & 0.82 & 0.68 \\
\hline Shannon diversity $\left(H^{\prime}\right)$ & 1.93 & 4.77 & 4.15 & 3.92 & 4.65 & 2.36 & 2.94 & 3.36 & 3.47 & 3.4 & 2.7 & 3.11 & 2.64 \\
\hline \multicolumn{14}{|l|}{ Fungi } \\
\hline OTU numbers & 11 & 106 & 15 & 12 & 124 & 12 & 10 & 10 & 16 & 20 & - & 10 & 13 \\
\hline Chao richness & 12.5 & 164 & 8.5 & 18 & 178 & 22 & 25 & 17.5 & 12.5 & 35 & - & 26.5 & 49 \\
\hline Shannon evenness $\left(J^{\prime}\right)$ & 0.32 & 0.45 & 0.15 & 0.13 & 0.61 & 0.59 & 0.33 & 0.47 & 0.03 & 0.30 & - & 0.25 & 0.32 \\
\hline Shannon diversity $\left(H^{\prime}\right)$ & 0.76 & 2.12 & 0.20 & 0.32 & 2.93 & 1.46 & 0.76 & 1.07 & 0.08 & 0.78 & - & 0.68 & 0.84 \\
\hline
\end{tabular}

(i) The letter "P" represents planted HSSF CWs; (ii) the letter "S" represents unplanted HSSF CWs; (iii) the letter "T" represents treatment; (iv) the letter "C" represents control; and (v) the numbers " 1 ," " 2 ," and " 3 " represent the sampling time

rRNA gene libraries, 2156 OTUs have been identified at a $3 \%$ distance across the 12 samples and 652 OTUs were found to be shared among two or more samples. Most of the samples from the control beds presented higher OTU numbers than those in the caffeine-treated beds for both the bacterial and fungal communities after the libraries were normalized by randomization to smallest library (Table 4).

The analytical results of Shannon-Weiner's indices $\left(H^{\prime}\right)$ showed that bacterial diversity decreased by 25 and $22.4 \%$ in both planted and unplanted wetland mesocosms after exposure to caffeine. On the contrary, Shannon-Weiner's indices $\left(H^{\prime}\right)$ for the fungal community in the mesocosms enriched with caffeine were higher $(p>0.05)$ than that in the control beds. A variety of previous studies have calculated $H^{\prime}$ values in aquatic ecosystems, and the values typically range from 0.5 to 5, with values of $0.5-2.0$ indicating low diversity and values of 2.0-5.0 indicating high diversity (Garrido et al. 2014). In the present study, most of $H^{\prime}$ values for the wetland bacterial communities were higher than 2.0 and were in a range of 1.93-4.77, suggesting a relatively wide range of bacterial diversity. However, most of $H^{\prime}$ values for the fungal community were lower than 2.0 (with a range of $0.20-2.12$ ), implying a relatively lower diversity compared to bacterial community.

Rarefaction curves, which describe the species richness as a function of sampling effort at a 0.03 distance cutoff, are plotted with sequence number of 16S rRNA against OTU numbers in different wetland mesocosms (Supplementary Fig. 2). Rarefaction curves generated for 16S rRNA bacteria (a) and 18S rRNA fungi (b) are based on taxonomic pyrosequencing in different wetland mesocosms, calculated by MOTHUR with a $3 \%$ distance cutoff. For most of rarefaction curves shown in Supplementary Fig. 2, their flat slopes indicate that a large fraction of the species diversity has been sampled.

\section{Similarity of microbial community structure}

NMDS allows a visualization of the distance relationships among the samples and provides an insight into their level of dispersion (Fig. 1). A noticeable difference between planted and unplanted as well as control and caffeine-treated mesocosms was observed in the present study. Using 0.6 as a benchmark (McLellan et al. 2010), for the planted mesocosms, all the control samples were clustered together and did not group with the caffeine-treated mesocosms, implying a notable dissimilarity in bacterial community between the caffeine-treated mesocosms and the control beds (Fig. 1b). This condition was even more pronounced in the last sampling period. For the unplanted mesocosms, the bacterial communities retrieved from the caffeine-treated mesocosms are also clustered together, but the dissimilarity between caffeinetreated and untreated systems was not as obvious with S1_C and $\mathrm{S} 2$ - T clustering together with a similarity of $60 \%$ and S3_C and S3_T clustering together at a $50 \%$ similarity (Fig. 1c). Therefore, although our results suggest strong evidence fo the shifts in community structure as a result of caffeine exposure, the existence of some notable outliers in these similarity plots indicates that such a conclusion cannot be definitive and points to the need for further lines of inquiry down this path.

In contrast, with respect to the fungal community, high similarity was observed between caffeine-treated and control-planted mesocosms (Fig. 1e). However, for the unplanted beds, caffeine-treated beds presented a remarkable dissimilarity to the control (Fig. 1f). Moreover, it is worth 


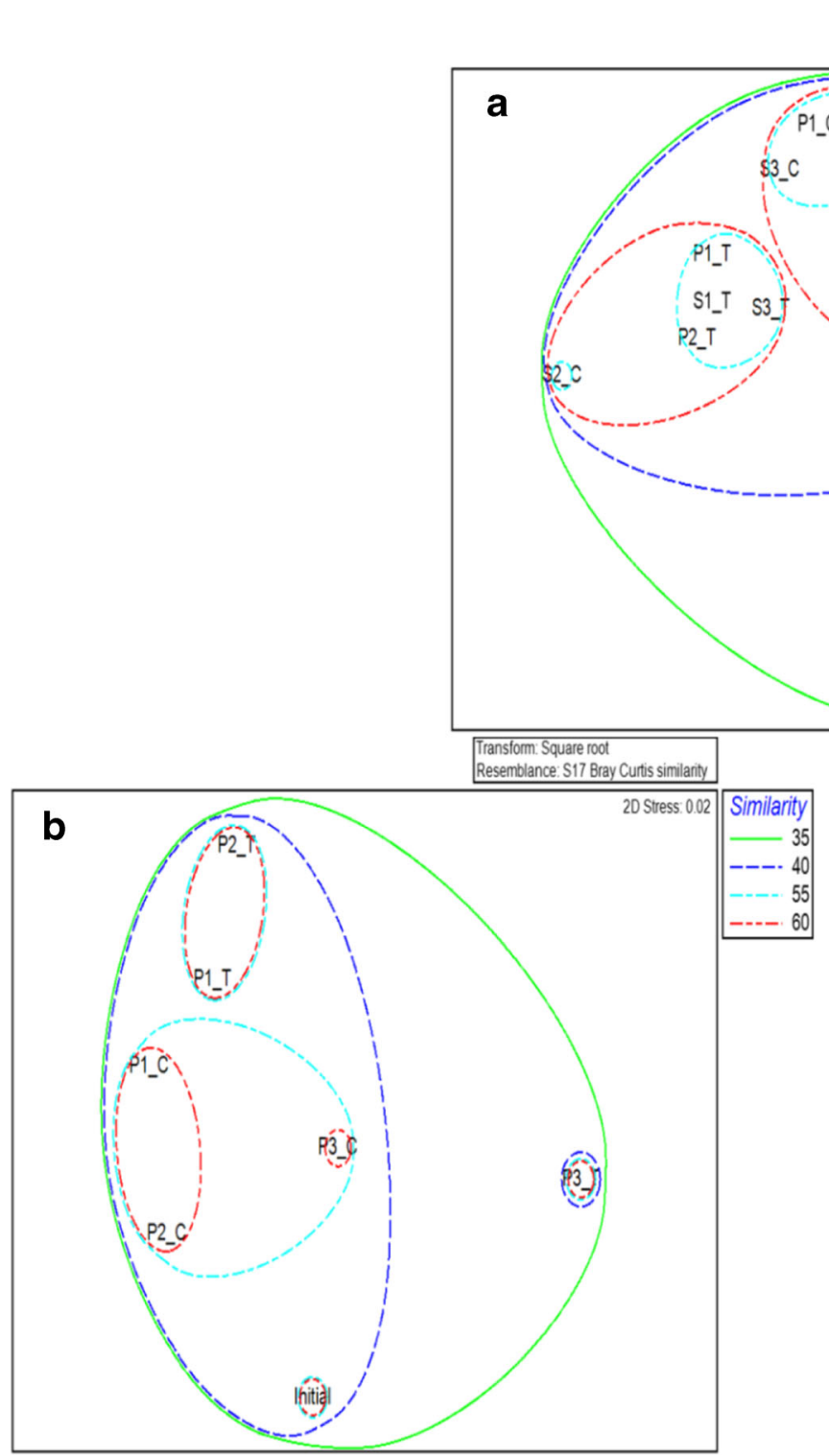

Fig. 1 Non-multidimensional scaling (NMDS) analysis of microbial community phylogenetic distance at class level derived from pyrosequencing bacterial $16 \mathrm{~S}$ rRNA genes and fungal $18 \mathrm{~S}$ rRNA genes, a bacterial community for both planted and unplanted mesocosms, b bacterial community for planted mesocosms, $\mathbf{c}$ bacterial community for unplanted mesocosms, $\mathbf{d}$ fungal community for both

noting that a significantly temporal variation was observed for the unplanted mesocosms over time, suggesting the dynamic microbial communities and biotic/abiotic processes throughout the whole experiment. When comparing the microbial community between planted and unplanted mesocosms, a distinct community profile for both bacteria and fungi was observed in the planted mesocosms with similarities less than $40 \%$ relative to unplanted mesocosms (Fig. 1a, d). These findings can also be illustrated by a dendrogram which was constructed to provide a visual presentation of the dissimilarity between the different treatment regimes (Supplementary Fig. 3).
Transtorm Square root

Resemblance: S17 Bray Curtis similanty
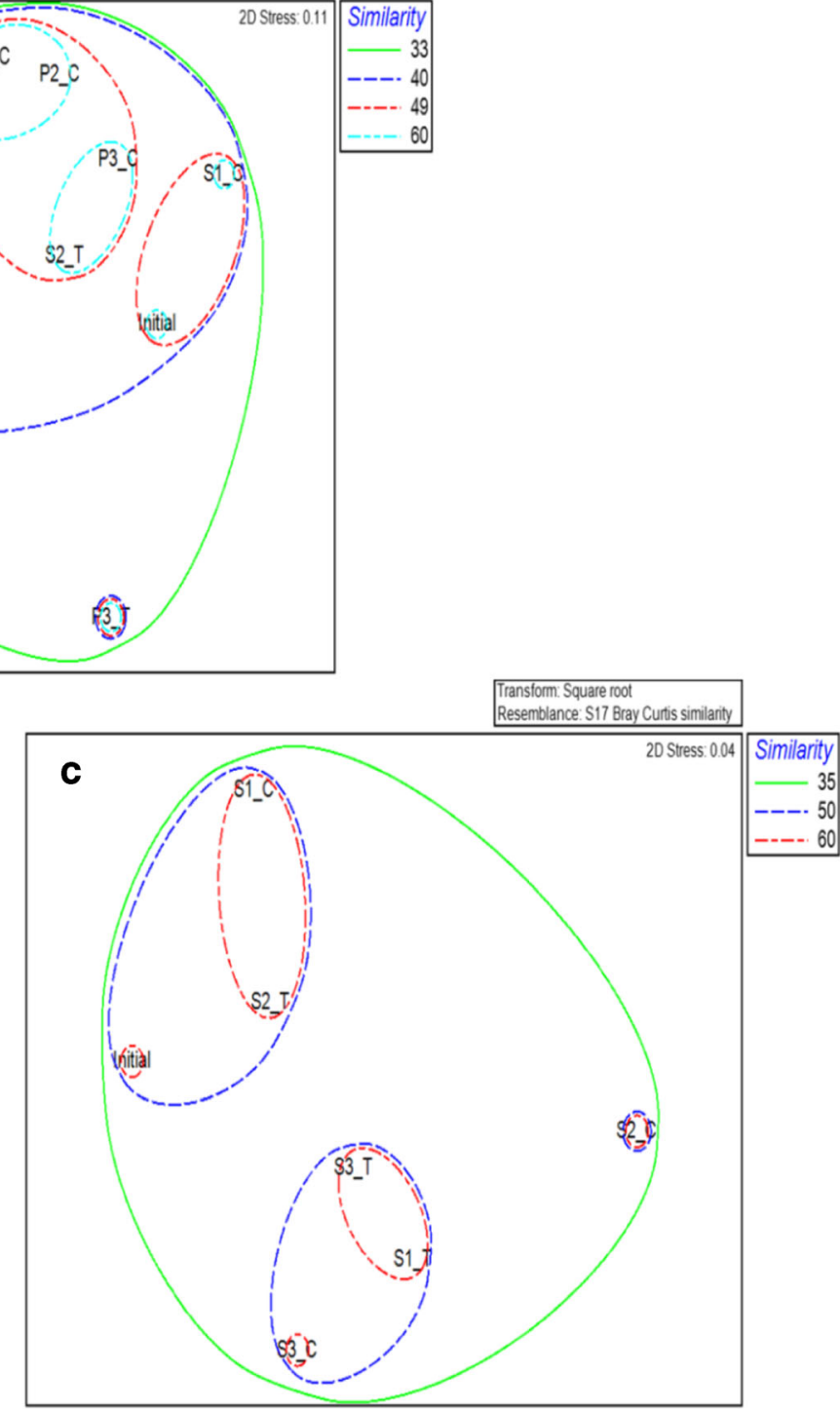

planted and unplanted mesocosms, e fungal community for planted mesocosms, and $\mathbf{f}$ fungal community for unplanted mesocosms. (i) Letter " $P$ " represents planted beds; (ii) letter " $S$ " represents unplanted beds; (iii) letter " $T$ " represents treatment; (iv) letter " $C$ " represents control; and (v) numbers " 1, , " 2 ," and " 3 " represent the sampling time

\section{Composition of microbial community}

In total, 20 bacterial phyla comprising 260 genera were identified in the present study. Across all soil samples, Firmicutes (averaging $39 \%$ ) represented the most abundant phyla, followed by Actinobacteria (25.1\%) and Proteobacteria $(17.1 \%)$. The other predominant phyla $(>1 \%)$ were Synergistetes (5.6 \%), Chloroflexi (5.5\%), Bacteroidetes (2.9\%), and Acidobacteria (1.0\%; Fig. 2a). It was also noticed that besides the dominant microbes, as many as $3.3 \%$ of total sequences could not be assigned to the phylum level. The 


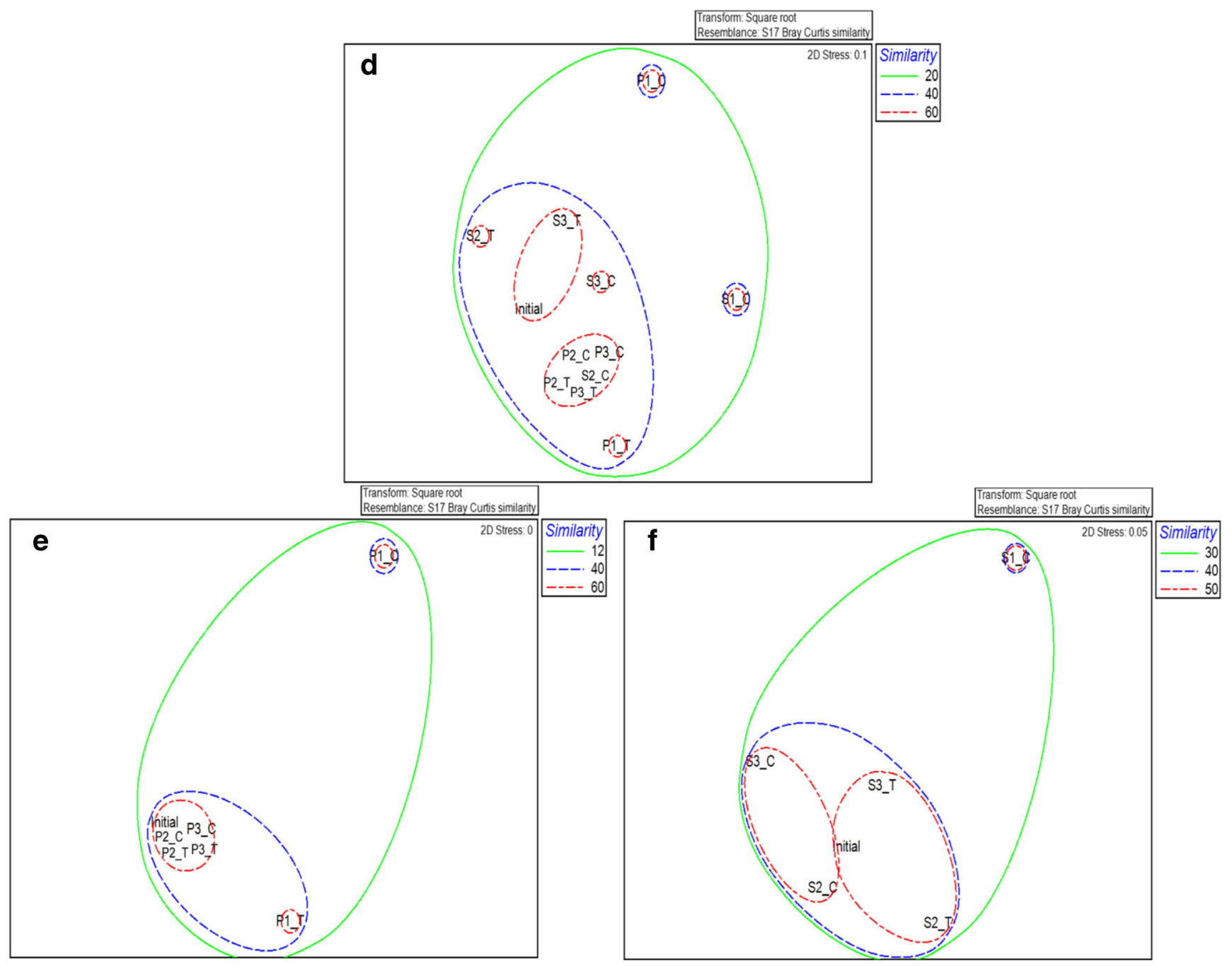

Fig. 1 (continued)

relative abundances of these groups roughly paralleled the major taxa found in wetland substrate media (Janssen 2006).

At the class level, broad taxonomic analyses revealed that a total of 46 bacterial taxa were found, and the most predominant bacteria ( $>1 \%$ ) were affiliated with Bacilli (33.4 \%), followed by Actinobacteria (25.4 \%), Gammaproteobacteria (8.3\%), Clostridia (5.6\%), Synergistia (4.8\%), Anaerolineae (4.7\%), Alphaproteobacteria (3.6\%), Betaproteobacteria (3.4\%), and Bacteroidetes (1.2 \%; Fig. 2b).

Among the assigned 260 genera, the most abundant $(>1 \%)$ bacteria were affiliated with Propionibacterium (16.9\%), Staphylococcus (9.3\%), Anaerolineaceae (8.1\%), Bacillus (5.8 \%), Staphylococcus (5.0 \%), unclassified Synergistaceae (2.9\%), Streptococcus (2.7\%), Escherichia/Shigella (2.6\%), unclassified Enterobacteriaceae (2.1\%), Granulicatella (2.0\%), and Clostridium (1.4\%; Fig. 2c). The high abundance of Propionibacterium was somewhat surprising. However, Hayashi and Furusaka (1979) similarly found that the population of Propionibacterium in the flooded paddy soils they studied was about 10 times higher than that of Clostridium, a value most similar to their respective abundance in the present study. As well, Streptococci were also shown to represent a major segment of the bacterial flora of indigenous to a variety of soils (Gledhill and Casida 1969). The moderate abundance shown by Escherichia/Shigella was also unexpected as the mesocosm's inflow in this study was synthetic wastewater presumably without fecal bacteria. However, in recent years, the growth of Escherichia coli in soils, sediments, and water in tropical and subtropical regions has been widely documented, and the organism is considered to be an established part of the soil biota within these regions (Byappanahalli and Fujioka 1998, 2004). Table 5 shows the taxonomic affiliation obtained from pyrosequencing with closest cultured matches according to the results of $16 \mathrm{~s}$ rDNA sequence match from RDP.

Additionally, high-throughput sequencing technology has the ability to identify a greater number of sequences than 
a Bacteria - Phylum Level Distribution

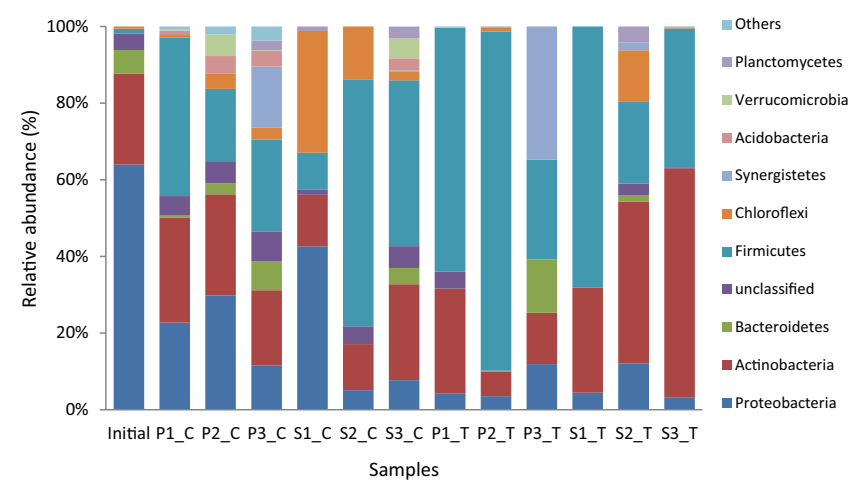

C

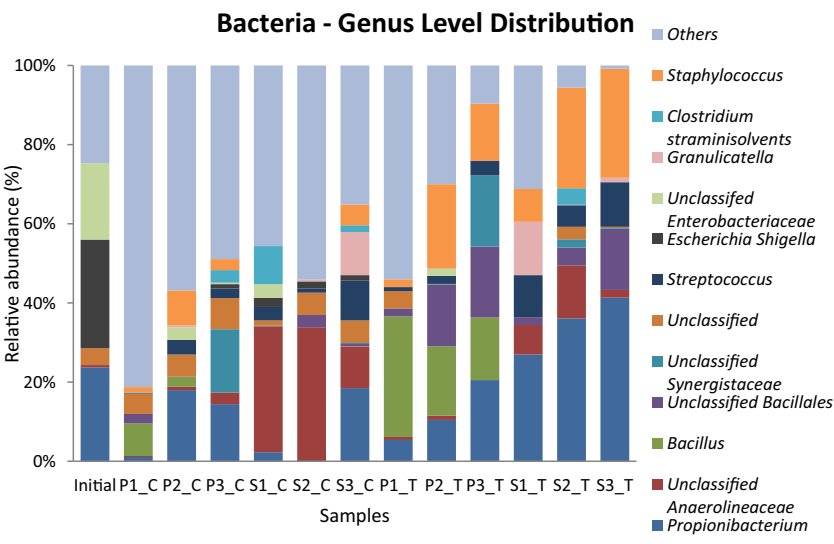

Fig. 2 Composition of bacterial community of 16S rRNA sequences from wetland mesocosms. Relative abundance was calculated by running R program. a Bacteria - phylum-level distribution, $\mathbf{b}$ bacteriaclass-level distribution, $\mathbf{c}$ bacteria-genus-level distribution, and $\mathbf{d}$

traditional DNA approaches, expediting the detection of more unknown sequences and those with low abundance as compared to traditional clone library approaches that, in turn, assist in the discovery of more new species (Roh et al. 2010). Therefore, it was not surprising that the percentage of unclassified bacteria has increased with the depth of classification. In the present study, significant percentage of genera such as unclassified Anaerolineaceae (Chloroflexi; $8.1 \%$ ), unclassified Synergistaceace (Synergistetes; $6.1 \%$ ), unclassified Clostridiales (Firmicutes; $2.2 \%$ ), unclassified $\beta$ Proteobacteria ( $\beta$-Proteobacteria; $1.6 \%$ ), and unclassified Bacteroidetes (Bacteroidetes; $1.2 \%$ ) belong to hidden diversity of unknown or uncultured species (Table 5), suggesting that most 16S rRNA gene sequences might be from bacteria that are not associated with known genera (Janssen 2006).

In the present study, the substrate media of the wetlands were dominated by the following seven major fungal groups at genus level: Aspergillus (16.3\%), Chaetomium (14.1\%), Phoma (6.2\%), Pleospora (3.5\%), Emericellopsis (3.3\%), Ganoderma (3.0\%), and Cladosporium (2.2 \%). It is noteworthy that uncultured fungus accounted for $51.4 \%$ of the total fungal sequences. b

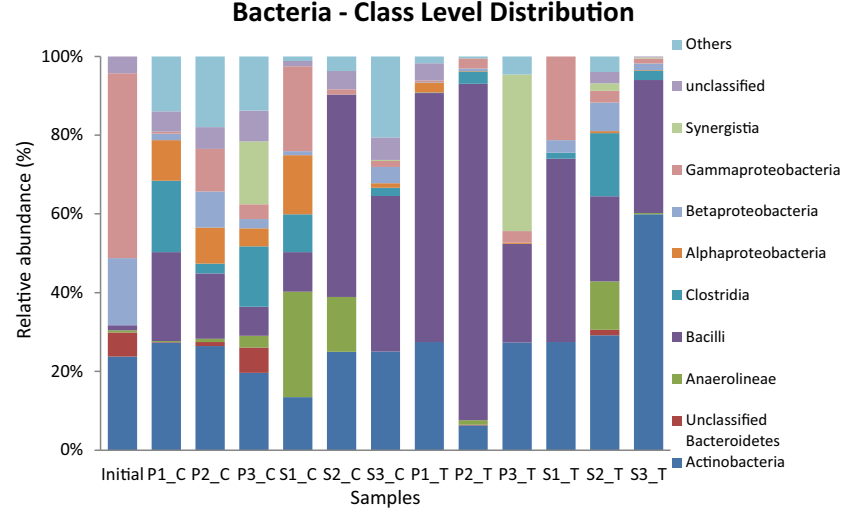

d

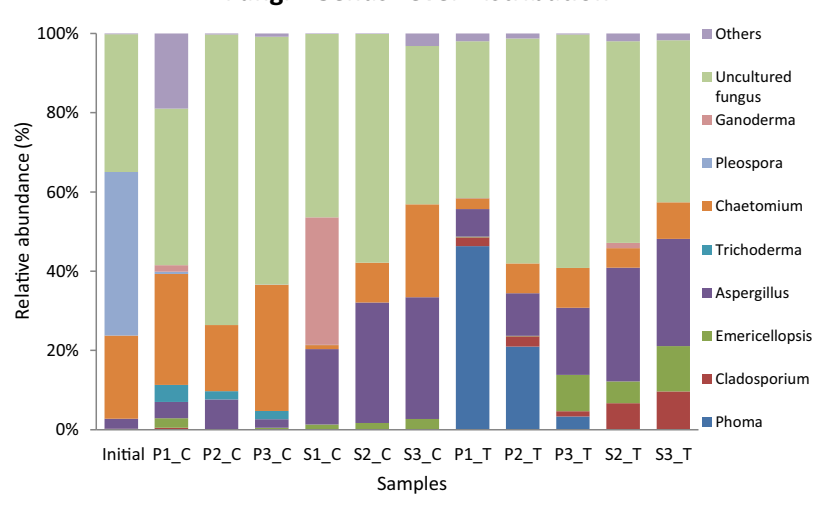

fungi—genus-level distribution. (i) The letter " $P$ " represents planted HSSF CWs; (ii) the letter " $S$ " represents unplanted HSSF CWs; (iii) the letter " $T$ " represents treatment; (iv) the letter " $C$ " represents control; and (v) the numbers "1," "2," and " 3 " represent the sampling time

\section{The impact of caffeine on microbial community}

In this study, the results of taxonomic analyses suggested that chronic exposure of wetland ecosystems to caffeine could lead to moderate shifts in microbial community composition. Some bacteria exhibited remarkable increase in abundance after caffeine treatment, implying that these highly capable for stress-tolerance bacteria could apparently adapt best to changes in the external environment. On the other hand, other members of the microbial community may be reduced in abundance whether that be they are outcompeted (i.e., caffeine serves as food source for other species) or sensitive (i.e., caffeine acts as an antimicrobial). It has been reported in earlier studies that caffeine at a relatively low concentration was antimicrobial and resulted in inhibition of growth and death of bacterial strains like $E$. coli and other bacterial strains particularly upon addition of caffeine at $\log$ phase of growth (Dash and Gummadi 2006; Gummadi et al. 2012). Indeed, Ramanavièienë et al. (2002) found that the growth of E. coli was inhibited significantly at caffeine concentrations as low as $1 \mathrm{~g} / \mathrm{L}$. 
Table 5 The taxomatic affiliation obtained from pyrosequending with closest cultured matches according to the results of 16s rDNA sequence match from Ribosomal Database Project (RDP and GenBank)

\begin{tabular}{|c|c|c|c|c|c|c|}
\hline OTU number & $\begin{array}{l}\text { Phylogentic } \\
\text { affiliation } \\
\text { at phylum level }\end{array}$ & $\begin{array}{l}\text { Phylogenetic } \\
\text { affiliation } \\
\text { at genus level }\end{array}$ & $\begin{array}{l}\text { Closest relative } \\
\text { species }\end{array}$ & $\begin{array}{l}\text { NCBI } \\
\text { accession no. }\end{array}$ & Similarity $(\%)$ & $\begin{array}{l}\text { Averaging relative } \\
\text { abundance }(\%)\end{array}$ \\
\hline
\end{tabular}

Phylum Firmicutes

OTU00045 Firmicutes

OTU00030 Firmicutes

OTU00011 Firmicutes

OTU00176 Firmicutes

OTU00002 Firmicutes

OTU00042 Firmicutes

OTU00269 Firmicutes

OTU00090 Firmicutes

OTU00023 Firmicutes

OTU00446 Firmicutes

OTU00043 Firmicutes

OTU00123 Firmicutes

OTU00237 Firmicutes

OTU00018 Firmicutes

OTU00117 Firmicutes

OTU00053 Firmicutes

Phylum Actinobacteria

OTU00001 Actinobacteria

OTU00026 Actinobacteria

OTU00096 Actinobacteria

OTU00612 Actinobacteria

OTU00313 Actinobacteria

OTU00071 Actinobacteria

OTU00639 Actinobacteria

Phylum Proteobacteria

Unclassified Bacillales
Bacillus
Streptococcus
Granulicatella
Unclassified Clostridiales
Staphylococcus
Unclassified Planococcacea
Unclassified
$\quad$ Planococcaceae
incertae_sedis
Ammoniphilus
Sporosaricina
Anaerococcus
Unclassified
Clostridiaceae_1
Clostridium_sensu
stricto
Geobacillus
Unclassified_Clostridiales
Incertae_Sedis_SI
Pelotomaculum
Peptomiphilus

Propionibacterium

Corynebacterium

Micrococcus

Unclassified Actinomycetales

Mycobacterium

Unclassified Actinobacteria

Nocardioides

Unclassified Bacillales
Bacillus vireti
Streptococcus oralis
Granulicatella
para-adiacens
Unclassified Clostridiales
Staphylococcus epidermidis
Unclassified Planococcaceae
Unclassified
$\quad$ Planococcaceae
incertae_sedis
Ammoniphilus spp.

Sporosaricina globispore

Anaerocoddus octavius

Unclassified

Clostridiaceae 1

Clostridium

chromiireducens

Geobacillus

thermodenitrificans

Unclassified Clostridiales Incertae_Sedis_SI

Uncultured bacterium

Peptoniphilus spp.

Propionibacterium acnes

Corynebacterium segmentosum

Micrococcus luteus

Unclassified Actinomycetales

Mycobacterium

moriokaense

Unclassified Actinobacteria

Nocardioides albus

Unclassified

Enterobacteriaceae

Escherichia coli

Serratia quinivorans

Unclassified

Betaproteobacteria

Unclassified Rhizobiales

Unclassified Proteobacteria

Unclassified

Comamonadaceae

Pseudomonas oryzihabitans

Methylosinns trichosporium

Uncultured bacterium

Unclassified Burkholderiales incertae_sedis

Pseudovibrio denitrificans

$\begin{array}{lll}\text { na } & 98.2 & 5.0 \\ \text { EU221372 } & 100 & 5.8 \\ \text { GU045378 } & 100 & 4.2 \\ \text { AY879298 } & 100 & 2.2 \\ \text { na } & 75.8 & 2.2 \\ \text { AY730712 } & 100 & 1.3 \\ \text { na } & 100 & 0.7 \\ \text { na } & 96.8 & 0.7\end{array}$

$\begin{array}{lll}\text { GQ062548 } & 98.7 & 0.7\end{array}$

$\begin{array}{lll}\mathrm{AB} 681045 & 97 & 0.6\end{array}$

$\begin{array}{lll}\text { Y07841 } & 100 & 0.5\end{array}$

$\begin{array}{lll}\text { na } & 97 & 0.5\end{array}$

$\begin{array}{lll}\text { AY228334 } & 97 & 0.4\end{array}$

$\begin{array}{lll}\text { AF114426 } & 100 & 0.4\end{array}$

$\begin{array}{lll}\text { na } & 100 & 0.3\end{array}$

$\begin{array}{lll}\text { AB853918 } & 94.7 & 0.2\end{array}$

$\begin{array}{lll}\text { AM176529 } & 100 & 0.2\end{array}$

$\begin{array}{lll}\mathrm{AB} 108480 & 100 & 16.9\end{array}$

$\begin{array}{lll}\mathrm{X} 84437 & 100 & 0.9\end{array}$

$\begin{array}{lll}\text { AF057289 } & 100 & 0.9\end{array}$

$\begin{array}{lll}\text { na } & 90.2 & 0.7\end{array}$

$\begin{array}{lll}\text { AJ429044 } & 100 & 0.5\end{array}$

$\begin{array}{lll}\text { na } & 95.8 & 0.3\end{array}$

$\begin{array}{lll}\text { AF004989 } & 100 & 0.2\end{array}$

$\begin{array}{lll}\text { na } & 100 & 2.7\end{array}$

$\begin{array}{lll}\text { AP009048 } & 99 & 2.2\end{array}$

$\begin{array}{lll}\text { AJ233435 } & 100 & 1.7\end{array}$

na $\quad 100 \quad 1.6$

na $\quad 100 \quad 1.5$

$\begin{array}{lll}\text { na } & 96.4 & 0.5\end{array}$

$\begin{array}{lll}\text { na } & 100 & 0.5\end{array}$

$\begin{array}{lll}\text { HM755542 } & 100 & 0.4\end{array}$

$\begin{array}{lll}\text { AB648997 } & 90.4 & 0.3\end{array}$

$\begin{array}{lll}\text { GQ007555 } & 100 & 0.2\end{array}$

$\begin{array}{lll}\text { na } & 94.7 & 0.2\end{array}$

$\begin{array}{lll}\text { AB681263 } & 100 & 0.2\end{array}$ 
Table 5 (continued)

\begin{tabular}{|c|c|c|c|c|c|c|}
\hline OTU number & $\begin{array}{l}\text { Phylogentic } \\
\text { affiliation } \\
\text { at phylum level }\end{array}$ & $\begin{array}{l}\text { Phylogenetic } \\
\text { affiliation } \\
\text { at genus level }\end{array}$ & $\begin{array}{l}\text { Closest relative } \\
\text { species }\end{array}$ & $\begin{array}{l}\text { NCBI } \\
\text { accession no. }\end{array}$ & Similarity $(\%)$ & $\begin{array}{l}\text { Averaging relative } \\
\text { abundance (\%) }\end{array}$ \\
\hline \multicolumn{7}{|c|}{ Phylum Chloroflexi } \\
\hline OTU00028 & Chloroflexi & $\begin{array}{l}\text { Unclassified } \\
\text { Anaerolineaceae }\end{array}$ & $\begin{array}{l}\text { Unclassified } \\
\text { Anaerolineaceae }\end{array}$ & na & 100 & 8.1 \\
\hline OTU00101 & Chloroflexi & $\begin{array}{l}\text { Unclassified } \\
\text { Ktedonobacterales }\end{array}$ & $\begin{array}{l}\text { Unclassified } \\
\text { Ktedonobacterales }\end{array}$ & na & 66.9 & 0.4 \\
\hline \multicolumn{7}{|c|}{ Phylum Synergistetes } \\
\hline OTU00074 & Synergistetes & $\begin{array}{l}\text { Unclassified } \\
\text { Synergistaceace }\end{array}$ & $\begin{array}{l}\text { Unclassified } \\
\text { Synergistaceace }\end{array}$ & na & 91.1 & 6.1 \\
\hline \multicolumn{7}{|c|}{ Phylum Bacteroidetes } \\
\hline OTU00041 & Bacteroidetes & $\begin{array}{l}\text { Unclassified } \\
\text { Bacteroidetes }\end{array}$ & $\begin{array}{l}\text { Unclassified } \\
\text { Bacteroidetes }\end{array}$ & na & 97.1 & 1.2 \\
\hline OTU00204 & Bacteroidetes & Cloacibacterium & Uncultured bacterium & DQ337018 & 100 & 1.0 \\
\hline OTU00344 & Bacteroidetes & $\begin{array}{l}\text { Unclassified } \\
\text { Chitinophagaceae }\end{array}$ & $\begin{array}{l}\text { Unclassified } \\
\text { Chitinophagaceae }\end{array}$ & na & 90.8 & 0.5 \\
\hline OTU00425 & Bacteroidetes & $\begin{array}{l}\text { Unclassified } \\
\quad \text { Porphyromonadaceae }\end{array}$ & $\begin{array}{l}\text { Unclassified } \\
\text { Porphyromonadaceae }\end{array}$ & na & 100 & 0.2 \\
\hline \multicolumn{7}{|c|}{ Phylum Verrucomicrobia } \\
\hline OTU00135 & Verrucomicrobia & Optitutus & Uncultured bacterium & DQ404823 & 95.6 & 0.7 \\
\hline \multicolumn{7}{|c|}{ Phylum Acidobacteria } \\
\hline OTU00049 & Actinobacteria & GP4 & Uncultured bacterium & HQ697521 & 90.2 & 0.5 \\
\hline
\end{tabular}

na not applicable

At class level, the Bacilli (57.9 \pm 7.1 versus $15.5 \pm 1.9 \%$ ) and Synergistia (13.3 \pm 3.4 versus $5.3 \pm 0.8 \%$ ) phyla increased in abundance in the planted mesocosms, while for the unplanted mesocosms, Actinobacterial (39.8 \pm 7.6 versus $21.1 \pm 5.4 \%$ ), Clostridia ( $7.2 \pm 1.1$ versus $3.9 \pm 0.4 \%$ ), and Betaproteobacteria $(4.3 \pm 0.6$ versus $1.6 \pm 0.2 \%)$ exhibited increases after exposure to caffeine.

At the genus level, the exposure of caffeine caused an increase of total sequences of Propionibacterium (12.4 $\pm 2.8 \%$ in the planted beds and $35.0 \pm 4.3 \%$ in the unplanted beds), compared to the control beds $(11.1 \pm 1.9$ and $6.9 \pm 1.1 \%$, respectively). Similarly, pyrosequencing analysis revealed a remarked increase in abundance for Staphylococcus after caffeine exposure ( $12.8 \pm 2.8$ versus $4.3 \pm 0.8 \%$ for planted beds and $21.5 \pm 4.4$ versus $1.7 \pm 0.3 \%$ for unplanted beds). The presence of caffeine also increased Bacillus in the planted beds $(21.5 \pm 4.1$ versus $3.5 \pm 0.5 \%$; Fig. 2 c). A significant increase was also observed for unclassified Synergistaceae after caffeine exposure $(18.3 \pm 4.3$ versus $5.3 \pm 1.0 \%$ and $0.7 \pm 0.2$ versus $0.1 \pm 0.02 \%$ ). These specific genera have been reported in previous studies to have unique catabolic machinery for the breakdown of various contaminants (Dong and Reddy 2010; Vymazal 2007). Bacillus, which is ubiquitously found in wetland substrate media and capable of high resistance to environmental insults due to its ability to form spores, has been extensively reported to have the potential for solubilizing phosphate (Dong and Reddy 2010), denitrification (Vymazal 2007), and pharmaceutical wastewater treatment in wetland systems (Chaturvedi et al. 2008). Staphylococcus has been commonly used in bioremediation for the treatment of various wastewaters, including chromatecontaminated industrial wastewater (Vatsouria et al. 2005), brewery wastewater (Zhang et al. 2007), and textile dye wastewater (Elisangela et al. 2009). Synergistaceae has been intensively found in the anaerobic processes for the treatment of various wastewaters like slaughterhouse wastewater (Palatsi et al. 2011), rice straw fermentation liquor wastewater (Ducey and Hunt 2013), industrial oil recovery wastewater (Garcia-Mancha et al. 2012), and swine wastewater (Ducey and Hunt 2013). The related changes in microbial structure that we observed most probably reflected a response of the microbial community to the disturbance of a balanced ecosystem. Moreover, the high removal efficiencies of caffeine observed throughout the study suggest that the selected microbial community not only was able to tolerate the disturbance but also participate in caffeine biodegradation. Future research must now be dedicated to finding out the underlying mechanisms that drive the community shifts and determining how these shifts may affect important wetland microbial community functions.

In contrast, the sensitive genera that were remarkably repressed in both planted and unplanted mesocosms after caffeine exposure were affiliated with unclassified Anaerolineaceae $(1.3 \pm 0.3$ versus $0.6 \pm 0.2 \%$ in the planted beds and 25.4 
\pm 4.5 versus $7.7 \pm 1.2 \%$ in the unplanted beds). E. coli ( 2.1 $\pm 0.4 \%)$ and Escherichia/Shigella $(2.6 \pm 0.2 \%)$ became even undetectable at the end of the experiment (Fig. 2c). Apparently, disturbance from contaminants such as caffeine will decrease the community of microbes to only those that are pollutanttolerant so that microorganisms that cannot adapt may no longer be a significant component of the community. Marked differences in the OTU values presented for the control and caffeine-treated mesocosms were also observed in the phylogenetic tree (Supplementary Fig. 4), which was constructed based on high-throughput pyrosequencing with a maximum likelihood algorithm. This was further checked by bootstrap calculations applying the Tamura-Nei model using program MEGA 6.

As for the response of fungal community to caffeine-enrichment, genera such as Cladosporium, Emericellopsis, Aspergillus, and Phoma were found to be resistant to caffeine disturbance, while Trichoderma, Chaetomium, and Ganoderma were inhibited and even undetectable after caffeine enrichment (Fig. 2d). Aspergillus is the most common occurring genera in sewage sludge (More et al. 2010). As a result, it has been extensively reported to have potential for heavy metal biosorption (Srivastava and Majumder 2008; Srivastava and Thakur 2006; Zafar et al. 2007), biosorption of reactive dye from textile wastewater (Khalaf 2008), and biodegradation and detoxification of industrial wastewaters (Fadil et al. 2003). Antagonistic Trichoderma are frequently found in soils in temperate regions and have been found with the pronounced ability to secrete diverse category of enzymes such as peroxidase, laccases, and oxidases which are responsible for the biodegradation of toxic organic compounds like polycyclic aromatic hydrocarbon (PAH) (Wang et al. 2006), anthracene, and fluoranthene in treatment wetlands (Giraud et al. 2001).

\section{The impacts of macrophytes on the microbial community}

The relationship between higher aquatic plants and microbial community in the treatment process has been arguable, due to the limited evidence both in experiments and practices (Baptista et al. 2008). Certain previous studies have indicated that plants do not exert a strong effect on the structure and diversity of the microbial community (Ahn et al. 2007; Gorra et al. 2007), while other studies have reported that macrophytes might be a significant driving force in influencing the structure of microbial communities (Calheiros et al. 2009; Osem et al. 2007). In the present study, the presence of plants increased the overall diversity of the microbial community, and there were significant $(p<0.05)$ differences in richness of microbial community between the planted and unplanted treatment wetlands (Table 4). Moreover, NMDS analysis revealed distinct community profiles for both bacteria and fungi in the planted mesocosms with similarities less than $40 \%$ relative to unplanted mesocosms (Fig. 1a, d). This suggests that the higher aquatic plant may well play a role in the shaping of the structure of the microbial community regardless of the caffeine disturbance. This finding is also consistent with findings by Weber et al. (2008) that showed that CWs operated similarly had communities with similar diversities, or in other words, that that the presence or absence of higher plant species can exert a significant effect on the overall composition of the microbial community.

In addition, the taxonomic analysis of the bacterial composition clearly indicated a distinct microbial community profile in the planted mesocosms compared to the unplanted beds. Since the process of caffeine catabolism is mostly aerobic (Gummadi et al. 2012), the presence of wetland plants may contribute to the aerobic degradation of caffeine through the release of oxygen from rhizosphere, which further promotes the interactions between plants and microorganisms. Moreover, plants can support large microbial populations in the rhizosphere through their secretion of organic exudates such as carbohydrates and amino acids (Brix 1997; Vymazal 2005). In the caffeine-treated planted mesocosms, Bacilli was the most predominant (25.0-63.2\%) followed by Actinobacteria (6.3$27.5 \%$ ) and Synergistia (0.2-39.8 \%), while for the caffeinetreated unplanted mesocosms, Actinobacteria was the most abundant (27.5-60.0 \%) followed by Bacilli (23.7-46.6\%) and Gammaproteobacteria (1.2-21.3\%; Fig. 2a). At genus level, regardless of the caffeine enrichment, the bacteria that were significantly $(p<0.05)$ increased in abundance in the presence of plants were affiliated to Bacillus $(3.5 \pm 0.6 \%$ in the control and $21.1 \pm 4.2 \%$ in the caffeine-treated beds) and unclassified Synergistaceae $(5.3 \pm 1.1$ and $6.3 \pm 0.7 \%)$, while in the unplanted beds, these two species were almost undetectable. Similarly, some OTUs, such as OTU 45 (Bacillus), OTU 46 (Bacillales), OTU 349 (Rhizobiales), and OTU 274 (Pseudomonas), were only present in the planted caffeinetreated mesocosms but not in the unplanted beds. On the contrary, the abundance of certain bacteria was noticeably $(p<0.05)$ decreased in the presence of the higher aquatic plant. These were Anaerolineaceace ( $25.4 \pm 3.6$ versus $1.3 \pm 0.4 \%$ and $7.6 \pm 1.8$ versus $0.6 \pm 0.2 \%)$ and Clostridium (3.9 \pm 0.9 versus $1.1 \pm 0.2 \%$ and $1.5 \pm 0.3$ versus $0.2 \pm 0.06 \%$ ) in both the control and caffeine-treated beds, respectively. Additionally, Staphylococcus also showed inhibition in the presence of plants after caffeine exposure $(21.5 \pm 4.8$ versus $12.8 \pm 3.1 \%$ ).

\section{Conclusions}

Microorganisms inhabiting CWs play a significant role in the biogeochemical cycles, making them key components of bioremediation processes. The characterization of microbial community in the planted and unplanted HSSF CWs receiving 
caffeine-enriched wastewater was investigated using a highthroughput pyrosequencing approach. The diversity of the bacterial community was reduced in the wetland system exposed to caffeine at the concentration of $250 \mathrm{mg} \mathrm{L}^{-1}$ during a 210-day period. Planted HSSF CWs exhibited significantly higher caffeine removal efficiencies compared to those in the unplanted HSSF CWs. A distinct profile of microbial community for the caffeine-enriched wetland mesocosms compared to the control was observed. The high caffeine removal efficiencies observed suggest that the selected microbial communities after caffeine enrichment were able to tolerate and adapt best to the environmental disturbance. The taxonomic analyses revealed that the presence of plant did exert significant effect on the microbial community structure.

\section{References}

Ahn C, Gillevet PM, Sikaroodi M (2007) Molecular characterization of microbial communities in treatment microcosm wetlands as influenced by macrophytes and phosphorus loading. Ecol Indic 7:852863

American Public Health Association (APHA) (1998) Standard methods for the examination of water and wastewater 20

Arroyo P, Sánenz de Miera LE, Ansola G (2015) Influence of environmental variables on the structure and composition of soil bacterial communities in natural and constructed wetlands. Sci Total Environ 506-507:380-390

Baker GC, Smith JJ, Cowan DA (2003) Review and re-analysis of domain-specific 16S primers. J Microbial Methods 55:541-555

Baptista JC, Davenport RJ, Donnelly T, Curtis TP (2008) The microbial diversity of laboratory-scale wetlands appears to be randomly assembled. Water Res 42:3182-3190

Brix H (1997) Do macrophytes play a role in constructed treatment wetlands? Water Sci Technol 35:11-17

Buée M, Reich M, Murat C, Morin E, Nilsson RH, Uroz S et al (2009) 454 pyrosequencing analyses of forest soils reveal an unexpectedly high fungal diversity. New Phytol 184:449-456

Buerge IJ, Poiger T, Müller MD, Buser HR (2003) Caffeine, an anthropogenic marker for wastewater contamination of surface waters. Environ Sci Technol 37:691-700

Byappanahalli MN, Fujioka RS (1998) Evidence that tropical soil environment can support the growth of Escherichia coli. Water Sci Technol 38(12):171-174

Byappanahalli MN, Fujioka RS (2004) Indigenous soil bacteria and low moisture may limit but allow faecal bacteria to multiply and become a minor population in tropical soils. Water Sci Technol 50(1):27-32

Calheiros CSC, Rangel AOSS, Castro PML (2009) Treatment of industrial wastewater with two-stage constructed wetlands planted with Typha latifolia and Phragmites australis. Bioresour Technol 100: 3205-3213

Chaturvedi S, Chandra R, Rai V (2008) Multiple antibiotic resistance patterns of rhizospheric bacteria isolated from Phragmites australis growing in constructed wetland for distillery effluent treatment. J Environ Biol 29:117-124

Dash SS, Gummadi SN (2006) Catabolic pathways and biotechnological applications of microbial caffeine degradation. Biotechnol Lett 28: 1993-2002
Dong X, Reddy GB (2010) Soil bacterial communities in constructed wetlands treated with swine wastewater using PCR-DGGE technique. Bioresour Technol 101:1175-1182

Dowd SE, Callaway TR, Wolcott RD, Sun Y, McKeehan T, Hagevoort RG et al (2008) Evaluation of the bacterial diversity in the feces of cattle using $16 \mathrm{~S}$ rDNA bacterial tag-encoded FLX amplicon pyrosequencing (bTEFAP). BMC Microbiol 8:125

Ducey TF, Hunt PG (2013) Microbial community analysis of swine wastewater anaerobic lagoons by next-generation DNA sequencing. Anaerobe 21:50-57

Elisangela F, Andrea Z, Fabio DG, de Menezes Cristiano R, Regina DL, Artur CP (2009) Biodegradation of textile azo dyes by a facultative Staphylococcus arlettae strain VN-11 using a sequential microaerophilic/aerobic process. Int Biodeterior Biodegrad 63:280-288

Fadil K, Chahlaoui A, Ouahbi A, Zaid A, Borja R (2003) Aerobic biodegradation and detoxification of wastewaters from the olive oil industry. Int Biodeterior Biodegrad 51:37-41

Foster ML, Dowd SE, Stephenson C, Steiner J, Suchodolski JS (2013) Characterization of the fungal microbiome (mycobiome) in fecal samples from dogs. Vet Med Int 2013:8

Garcia-Mancha N, Puyol D, Monsalvo VM, Rajhi H, Mohedano AF, Rodriguez JJ (2012) Anaerobic treatment of wastewater from used industrial oil recovery. J Chem Technol Biotechnol 87:1320-1328

Garrido L, Sánchez O, Ferrera I, Tomàs N, Mas J (2014) Dynamics of microbial diversity profiles in waters of different qualities. Approximation to an ecological quality indicator. Sci Total Environ 468-469:1154-1161

Giraud F, Guiraud P, Kadri M, Blake G, Steiman R (2001) Biodegradation of anthracene and fluoranthene by fungi isolated from an experimental constructed wetland for wastewater treatment. Water Res 35:4126-4136

Gledhill WE, Casida LE (1969) Predominant catalase-negative soil bacteria. III. Agromyces, gen. n., microorganisms intermediary to Actinomyces and Nocardia. Appl Environ Microbiol 18(3):340-349

Gorra R, Coci M, Ambrosoli R, Laanbroek HJ (2007) Effects of substratum on the diversity and stability of ammonia-oxidizing communities in a constructed wetland used for wastewater treatment. J Appl Microbiol 103:1442-1452

Gummadi SN, Bhavya B, Ashok N (2012) Physiology, biochemistry and possible applications of microbial caffeine degradation. Appl Microbiol Biotechnol 93:545-554

Hayashi S. Furusaka C (1979) Studies on Propionibacterium isolated from paddy soils. Ecology 45(4):565-574

Hijosa-Valsero M, Matamoros V, Martín-Villacorta J, Bécares E, Bayona JM (2010) Assessment of full-scale natural systems for the removal of PPCPs from wastewater in small communities. Water Res 44: $1429-1439$

Janssen PH (2006) Identifying the dominant soil bacterial taxa in libraries of 16S rRNA and 16S rRNA genes. Appl Environ Microbiol 72: $1719-1728$

Johnsen AR, Winding A, Karlson U, Roslev P (2002) Linking of microorganisms to phenanthrene metabolism in soil by analysis of $13 \mathrm{C}$ labeled cell lipids. Appl Environ Microbiol 68:6106-6113

Joss A, Zabczynski S, Göbel A, Hoffmann B, Löffler D, McArdell CS et al (2006) Biological degradation of pharmaceuticals in municipal wastewater treatment: proposing a classification scheme. Water Res 40:1686-1696

Khalaf MA (2008) Biosorption of reactive dye from textile wastewater by non-viable biomass of Aspergillus niger and Spirogyra sp. Bioresour Technol 99:6631-6634

Kolpin DW, Furlong ET, Meyer MT, Thurman EM, Zaugg SD, Barber LB et al (2002) Pharmaceuticals, hormones, and other organic wastewater contaminants in U.S. streams, 1999-2000: a national reconnaissance. Environ Sci Technol 36:1202-1211

Ligi T, Oopkaup K, Truu M, Preem J, Nõlvak H, Mitsch WJ, Mander Ü, Truu J (2014) Characterization of bacteria communities in soil and 
sediment of a created riverine wetland complex using highthroughput 16S rRNA amplicon sequencing. Ecol Eng 72:56-66

Ma J, Wang Z, Yang Y, Mei X, Wu Z (2013) Correlating microbial community structure and composition with aeration intensity in submerged membrane bioreactors by 454 high-throughput pyrosequencing. Water Res 47:859-869

Martinez Gomez DA, Baca S, Walsh EJ (2015) Lethal and sublethal effects of selected PPCPs on the freshwater rotifer, Plationus patulus. Environ Toxicol Chem 34:913-922

Matamoros V, Arias C, Brix H, Bayona JM (2009) Preliminary screening of small-scale domestic wastewater treatment systems for removal of pharmaceutical and personal care products. Water Res 43:55-62

Matamoros V, Nguyen LX, Arias CA, Salvadó V, Brix H (2012) Evaluation of aquatic plants for removing polar microcontaminants: a microcosm experiment. Chemosphere 88:1257-1264

McLellan SL, Huse SM, Mueller-Spitz SR, Andreishcheva EN, Sogin ML (2010) Diversity and population structure of sewage-derived microorganisms in wastewater treatment plant influent. Environ Microbiol 12:378-392

Mohapatra BR, Harris N, Nordin R, Mazumder A (2006) Purification and characterization of a novel caffeine oxidase from Alcaligenes species. J Biotechnol 125:319-327

Moore MT, Greenway SL, Farris JL, Guerra B (2008) Assessing caffeine as an emerging environmental concern using conventional approaches. Arch Environ Contam Toxicol 54:31-35

More TT, Yan S, Tyagi RD, Surampalli RY (2010) Potential use of filamentous fungi for wastewater sludge treatment. Bioresour Technol 101:7691-7700

Osem Y, Chen Y, Levinson D, Hadar Y (2007) The effects of plant roots on microbial community structure in aerated wastewater-treatment reactors. Ecol Eng 29:133-142

Palatsi J, Viñas M, Guivernau M, Fernandez B, Flotats X (2011) Anaerobic digestion of slaughterhouse waste: main process limitations and microbial community interactions. Bioresour Technol 102: 2219-2227

Quast C, Pruesse E, Yilmaz P, Gerken J, Schweer T, Yarza P et al (2013) The SILVA ribosomal RNA gene database project: improved data processing and web-based tools. Nucleic Acids Res 41:D590-D596

Ramanavièienë A, Žukienë V, Ačaitë J, Ramanavičius A (2002) Influence of caffeine on lysozyme activity in blood serum of mice. Acta Medica Lituanica 9(4):241-244

Roesch LFW, Fulthorpe RR, Riva A, Casella G, Hadwin AKM, Kent AD et al (2007) Pyrosequencing enumerates and contrasts soil microbial diversity. ISME J 1:283-290

Roh SW, Abell GCJ, Kim KH, Nam YD, Bae JW (2010) Comparing microarrays and next-generation sequencing technologies for microbial ecology research. Trends Biotechnol 28:291-299

Rosal R, Rodríguez A, Perdigón-Melón JA, Petre A, García-Calvo E, Gómez MJ et al (2009) Degradation of caffeine and identification of the transformation products generated by ozonation. Chemosphere 74:825-831

Schloss PD, Westcott SL, Ryabin T, Hall JR, Hartmann M, Hollister EB et al (2009) Introducing mothur: open-source, platform-independent, community-supported software for describing and comparing microbial communities. Appl Environ Microbiol 75:7537-7541

Solomon KR, Baker DB, Richards RP, Dixon KR, Klaine SJ, La Point TW et al (1996) Ecological risk assessment of atrazine in North American surface waters. Environ Toxicol Chem 15:31-76

Srivastava NK, Majumder CB (2008) Novel biofiltration methods for the treatment of heavy metals from industrial wastewater. J Hazard Mater 151:1-8
Srivastava S, Thakur IS (2006) Isolation and process parameter optimization of Aspergillus sp. for removal of chromium from tannery effluent. Bioresour Technol 97:1167-1173

Stottmeister U, Wießner A, Kuschk P, Kappelmeyer U, Kästner M, Bederski $\mathrm{O}$ et al (2003) Effects of plants and microorganisms in constructed wetlands for wastewater treatment. Biotechnol Adv 22:93-117

Thomas PM, Foster GD (2005) Tracking acidic pharmaceuticals, caffeine, and triclosan through the wastewater treatment process. Environ Toxicol Chem 24:25-30

Truu M, Juhanson J, Truu J (2009) Microbial biomass, activity and community composition in constructed wetlands. Sci Total Environ 407: 3958-3971

Vatsouria A, Vainshtein M, Kuschk P, Wiessner A, Kosolapov D, Kaestner M (2005) Anaerobic co-reduction of chromate and nitrate by bacterial cultures of Staphylococcus epidermidis L-02. J Ind Microbiol Biotechnol 32:409-414

Verlicchi P, Zambello E (2014) How efficient are constructed wetlands in removing pharmaceuticals from untreated and treated urban wastewaters? A review. Sci Total Environ 470-471:1281-1306

Vymazal J (2005) Horizontal sub-surface flow and hybrid constructed wetlands systems for wastewater treatment. Ecol Eng 25:478-490

Vymazal J (2007) Removal of nutrients in various types of constructed wetlands. Sci Total Environ 380:48-65

Wang JB, Chai LH, Zhang Y, Chen LM (2006) Microbial ecological model of filamentous bulking and mechanisms. World J Microbiol Biotechnol 22:1313-1320

Weber KP, Gehder M, Legge RL (2008) Assessment of changes in the microbial community of constructed wetland mesocosms in response to acid mine drainage exposure. Water Res 42:180-188

Ye L, Shao MF, Zhang T, Tong AHY, Lok S (2011) Analysis of the bacterial community in a laboratory-scale nitrification reactor and a wastewater treatment plant by 454-pyrosequencing. Water Res 45 : 4390-4398

Zafar S, Aqil F, Ahmad I (2007) Metal tolerance and biosorption potential of filamentous fungi isolated from metal contaminated agricultural soil. Bioresour Technol 98:2557-2561

Zhang Z, Lin B, Xia SQ, Wang XJ, Yang AM (2007) Production and application of a novel bioflocculant by multiple-microorganism consortia using brewery wastewater as carbon source. J Environ Sci 19: $667-673$

Zhang DQ, Tan SK, Gersberg RM, Zhu J, Sadreddini S, Li Y (2012a) Nutrient removal in tropical subsurface flow constructed wetlands under batch and continuous flow conditions. J Environ Manag 96:16

Zhang DQ, Gersberg RM, Hua T, Zhu J, Tuan NA, Tan SK (2012b) Pharmaceutical removal in tropical subsurface flow constructed wetlands at varying hydraulic loading rates. Chemosphere 87:273-277

Zhang DQ, Hua T, Gersberg RM, Zhu J, Ng WJ, Tan SK (2013) Fate of caffeine in mesocosms wetland planted with Scirpus validus. Chemosphere 90:1568-1572

Zhang D, Gersberg RM, Ng WJ, Tan SK (2014) Removal of pharmaceuticals and personal care products in aquatic plant-based systems: a review. Environ Pollut 184:620-639

Zhang DQ, Luo J, Zarraz MPL, Gersberg RM, Liu Y, Tan SK, Ng WJ (2015) Ibuprofen removal in horizontal subsurface flow constructed wetlands: treatment performance and fungal community dynamics. Environ Technol 18:1-33

Zhao C, Xie H, Xu J, Xu X, Zhang J, Hu Z, Liu C, Liang S, Wang Q, Wang J (2015) Bacterial community variation and microbial mechanism of triclosan (TCS) removal by constructed wetlands with different types of plants. Sci Total Environ 505:633-639 